\title{
SOCIAL AND LEGAL SUPERVISION AND CONTROL FOR COMPLIANCE WITH FACTORY LEGISLATION IN SCIENTIFIC VIEWS OF THE LATE XIX - EARLY XX CENTURY
}

\section{Halyna Terela}

\section{INTRODUCTION}

The establishment and development of an institution for supervision and control of labor legislation observance should be considered in general context of legislation system genesis, especially its sectoral components, such as administrative and labor law. This involves a comprehensive study of historical and theoretical section of the issue related to the explaining the legal nature of supervision and control in the labor sector as a form of social control, an objectively existing phenomenon of legal reality that has arisen, transformed and functions as a result of social relations development.

Theoretical cognition is considered in scientific literature as "object's history, ie logic of its development, formation, logic for its "organs" formation, its parts functions, logic of its integrity, logic of its process ..."1. Taking into account that the relations of supervision and control over the labor law observance are regulated in a legal form, and legal regulation is a form of state influence on public relations, it is obvious that clarifying the essential characteristics of supervision and control in statics and due to pricisely historical conditions in dynamics as well. The clarifying is possible according to a framework for a comprehensive genesis study of law institution regarding the genesis of a society, law and state. Following the appropriate remark by M. Miroshnychenko, “... it is necessary to reproduce in a theory of the true history referring to law and legal phenomena as organic aspects of society"2. Actually, the law history itself provides a wide range of information sources that allow scientific criteria evaluate social phenomena, theoretical conclusions on a solid basis of facts.

It is known that today there are different models of state supervision and labor inspection control in the world. We set a goal to find out the prerequisites and

${ }^{1}$ Il'in A.Ya.(ex. ed.), Molodcov V.S., Korshunov A.M. (1970) Metodologicheskie problemy sovremennoj nauki [Methodological problems of modern science]. Moscow: Izd-vo Mosk. un-ta. (in Russian), pp. 332-333.

2 Miroshnychenko M.I. (2012) Henezys pravovoi systemy Ukrainy: teoretykometodolohichnyi aspekt [Genesis of the legal system in Ukraine: theoretical and methodological aspect] (Doctor of Science Thesis), Kyiv: Open International University of Human Development «Ukraine», p. 87. 
peculiarities for the emergence of factory institution inspection as a specialized state body, designed to supervise and control the compliance with (labor, industrial) legislation; identify views as for the place and role of supervision and control in securing the rights of workers from the imperial period at the example of Ukraine, which in the late XIX - early XX centuries was divided between Russian and Austro-Hungarian empires.

The social essence of the phenomena in modern scientific literature is understood as "... the ability to serve as a means of meeting the needs (interests) of particular subjects of society" ". Such a feature of the legal phenomenon as "sociality" stems from the fact that the subjects of law are exclusively people and their origins. The emergence of legal norms cannot be imagined without the support of people's interests. The content of interest is based on the totality of human needs and lies in the conscious attitude of the subject to social environment, prerequisites and the necessity to meet such needs ${ }^{4}$.

The so-called "need" conceptual approach, interpreted in the 1980s as "... identifying the historically predetermined specific needs for the subjects of public life and establishing the role, function (potential, and real) of those or other objects, phenomena of such needs satisfaction" "will solve the problems of this study.

\section{Raising the problem on the necessity and limits of state intervention in the relationship between manufacturers and workers}

The establishment of supervision and control in the field of wage labor was accompanied by its organizational and legal form of factory inspection institution at the end of the nineteenth century. The legal system of Ukraine (divided between Russian and Austro-Hungarian empires) was at the stage of "legal centralization and neutralization of conditions for the development of national law" $"$. At the same time, legal practices and traditions were imprinted

${ }^{3}$ Rabinovych P., Lutsiv O. (2017) Verkhovenstvo prava yak omriianyi rezultat zdiisnennia prav liudyny (pidkhody do interpretatsii, kryterii otsiniuvannia) [Rule of law as a dreamy result of the realization of human rights (approaches to interpretation, evaluation criteria)]. Law of Ukraine, no. 3, p. 104.

${ }^{4}$ Honcharova K.V., Ivchuk Yu.Yu., Prylypko S.M., Yaroshenko O.M. (2014) Derzhava ta yii orhany yak subiekty trudovoho prava: teoretyko-prykladnyi narys [The State and its Bodies as Subjects of Labor Law: Theoretical and Applied Outline]. Kharkiv: Pravo. (in Ukrainian), p. 11.

${ }^{5}$ Rabinovych P., Lutsiv O. (2017) Verkhovenstvo prava yak omriianyi rezultat zdiisnennia prav liudyny (pidkhody do interpretatsii, kryterii otsiniuvannia) [Rule of law as a dreamy result of the realization of human rights (approaches to interpretation, evaluation criteria)]. Law of Ukraine, no. 3, p. 104.

6 Miroshnychenko M.I. (2012) Henezys pravovoi systemy Ukrainy: teoretykometodolohichnyi aspekt [Genesis of the legal system in Ukraine: theoretical and methodological aspect] (Doctor of Science Thesis), Kyiv: Open International University of Human Development «Ukraine», p. 188. 
within law enforcement practices. The legal opinion of the scientists at that time evolved, showing the substantiation of law concepts, differentiation of the police state and law-based state features, social nature of law, serving as "...a kind of key to understanding the laws, nature and tendencies of the development of law, which do not disappear with the change of socioeconomic formations, and undergo transformational changes in the process of state development"

The bourgeois revolutions within European countries recognized a number of human and citizen rights and freedoms based on traditional liberal values and defining the limits of state interference in private relations, reflecting the beginning of legal equality period due to the destruction of the feudal system. Léon Duguit explained the general tendency of new social development foundations: "State authority should subordinate to the power of law" .

It is known that the transition to bourgeois relations was delayed in Russian Empire, but this did not prevent the well-known scholars in the field of law and economics from discussing acute problems of further state-legal and social development. Thus, famous lawyer from Kyiv, Head for the Department of Legal Encyclopedia in Imperial University of St. Vladimir from 1871 to 1880 and a mayor ${ }^{9}$ of Kyiv in the period from 1875 to $1879-$ M. Rennenkampff, considering the role of the state in protecting the rights of citizens to prevent cases of "personal defense and lynching", noted the need for the latter to establish general and permanent surveillance measures ${ }^{10}$. The scientist attributed supervising to the measures of administrative protection of rights and laid the responsibility for its implementation upon the police, administrative and public authorities. So highlighting the private, public (state) and interstate law, M. Rennenkampff far-sightedly emphasized that "... time and state understand the meaning, boundaries, and correlation of law parts, so the systematization of law has its history which shows how due to the influence of certain conditions of reality different branches of law gradually

7 Zhyhalkin I.P. (2016) Systema pryntsypiv trudovoho prava $v$ umovakh formuvannia pravovoi doktryny Ukrainy [System of labor law principles in the conditions of legal doctrine in Ukraine formation] (Doctor of Science Thesis), Kyiv: Taras Shevchenko National University of Kyiv, p. 137.

${ }^{8}$ Djugi L. (1909) Social'noe pravo, individual'noe pravo i preobrazovanie gosudarstva [Social law, individual law and state transformation]. Moscow: Izdanie N.N. Klochkova. (in Russian), p. III.

${ }^{9}$ Hlyz Yu. (2013) Miskyi holova Kyieva M. K. Rennenkampf: sproba sotsiolohichnoho portretu [Kyiv Mayor M.K. Rennenkampff: an attempt of a sociological portrait]. Local History, no. 2, p. 191.

${ }_{10}$ Rennenkampf N.K. (1907) Juridicheskaja jenciklopedija [Legal Encyclopedia]. Kyiv; St. Petersburg: Izd. knigoprodavca N.Ya. Ogloblina [Lito-tipogr. T-va I.N. Kushnarev]. (in Russian), p. 202. 
emerged, the content was distributed between them and the relationship was established"11.

Ukrainian scientist, associate professor for the Department of Police Law in Imperial University of Saint Vladimir A. Antonovich, being, first of all, a scientist-economist, opposed the excessive government interference in the development of industry so that not to complicate private enterpreneurship with the measures of "excessive supervision". A. Antonovich emphasized that it is not so important to define a certain framework for the administrative activity of the state, but to establish such interaction between police bodies when it is possible to achieve national welfare, unconceivable, in his opinion, without personal freedom $1^{12}$.

Turning to the problem of rights and freedoms, Russian scientistadministrativist A. Yelistratov emphasized the anarchic essence of "absolute freedom", in his view it is incompatible with the tasks of a public nature assumed by the state, and defined the "right of personal freedom" as a set legal norms that determine the attitude of public authorities to the personal freedom of citizens, including the latter and "the right to work (sphere of economic activity of citizens)" 13 .

Therefore, one of the problems in the legal science, caused by the needs of public practice, was to justify the necessity and limits of state intervention in the relationship between industrialists and workers. There were highlited three main positions as for the so-called labor issue in the literature of that time. Proponents of the individualistic direction were opposed to any state intervention in the industrial sphere, they did not see the need for legal regulation of labor relations. This position prevailed in England for some time, it promoted the development of trade unions and their execution of the function for protecting the workers interests.

Contrary to the individualistic concept, the representatives of another extreme point of view emphasized the need for a comprehensive influence of state institutions on all social relations. V. Lytvynov-Falinsky rightly noted that such a position was most clearly manifested in Russian Empire, an agricultural country with a poorly developed industry and as a consequence:

11 Rennenkampf N.K. (1907) Juridicheskaja jenciklopedija [Legal Encyclopedia]. Kyiv; St. Petersburg: Izd. knigoprodavca N. Ja. Ogloblina [Lito-tipogr. T-va I. N. Kushnarev]. (in Russian), p. 202.

${ }^{12}$ Antonovich A.Ya. (1890) Kurs" gosudarstvennago blagoustroystva (politseyskago prava) [Public Improvement Course (Police Law)]. Kyiv: Tip. V.I. Zavadzkago, Vol. 1 (in Russian), p. 103.

${ }^{13}$ Elistratov A. I. (1910) Uchebnik' russkago administrativnogo prava. Posobie k' lektsiyam [Textbook of Russian administrative law. Lecture Manual]. Moscow: Izdanie O-va Vzaimopomoshchi Studentov-Yuristov Mosk. Universiteta Vol. I. (in Russian), p. 84. 
almost complete lack of individual activity of workers ${ }^{14}$. Factory legislation emerged in European countries when workers were free, in Russian Empire factory legislation was characterized by a shortage of freelance workers ${ }^{15}$.

When setting up a factory inspection in accordance with the Law "On juveniles working in factories, plants and manufactories" adopted on June 1, 1882, its powers were supervisory, albeit narrow in scope, extending to the verification of the labor use and the organization of schooling for juvenile workers. On June 3, 1886, with the adoption of the Law "Rules on Supervision of Factory Industries and Mutual Relations of Manufacturers and Workers", which gave the inspection a status of general supervisory body and enshrined the principle of state intervention, the activities of the latter acquired preventive and patronizing details of internal factory regulations and obligation upon inspectors to prevent inconsistencies and clashes between workers and industrialists by administrative influence. G. Shershenevych summarized the change of legislative policy as to the status of factory inspection from the body for protection the working class against exploitation by the factory owners it turned into the body for the police supervision over the workers loyalty.

The contemporary of the events G. Biletsky thought it was necessary to give factory inspection the powers "... to observe the preservation and integrity of the law - its essence, not its letter" $"$. V. Lytvynov-Falinsky tried to substantiate the feasibility of solving the misunderstandings between workers and industrialists "not formally, but in fairness" 17 with the help of inspection by giving various examples from practice. Such a view expressed by factory inspectors demonstrated the guardianship nature of the inspection activity, combination of its performance for both control and supervisory functions. Inspectors practiced interventions in the domestic affairs of enterprises, guided by "the essence of the law and their own discretion"18.

${ }^{14}$ Litvinov-Falinskiy V. p. (1904) Fabrichnoe zakonodatel'stvo i fabrichnaya inspektsiya $v$ Rossii [Factory legislation and factory inspection in Russia]. St. Petersburg: tip. A. S. Suvorina. (in Russian), p. XVIII.

${ }^{15}$ Shershenevich G.F. (1908) Kurs torgovogo prava. T. I: Vvedenie. Torgovye deyateli [Commercial law course. T. I: Introduction. Trading figures]. St. Petersburg: Izdanie Br. Bashmakovykh. (in Russian), p. 225.

16 Balitskiy G. (1907) Kakaya dolzhna byt' fabrichnaya inspektsiya [The way factory inspection should be]. Moscow. (in Russian), p. 32.

${ }^{17}$ Litvinov-Falinskiy V. p. (1904) Fabrichnoe zakonodatel'stvo i fabrichnaya inspektsiya $v$ Rossii [Factory legislation and factory inspection in Russia]. St. Petersburg: tip. A. S. Suvorina. (in Russian), p. 333-335.

${ }^{18}$ Zav'yalov M. F. (2013) Nadzor i kontrol' za soblyudeniem zakonodatel'stva o trude kak sposoby zashchity trudovykh prav rabotnikov [Supervision and monitoring of compliance with labor laws as the ways to protect labor rights of workers] ( $\mathrm{PhD}$ thesis abstract), Moscow: Institute of Legislation and Comparative Law under the Government of Russian Federation, p. 14. 
Russian Empire of the late nineteenth and early twentieth centuries, despite the increasing number of various regulations was characterized by legal arbitrariness, which was justified by the desire to provide a safe and prosperous living conditions for a person who, "by the way, was regarded as a juvenile, unable to understand what is good or bad for him"19.

L. Tal emphasized the peculiarity of regulating relations between industrialists and workers in Russian Empire. According to L. Tal, state intervention in the activity of industrial enterprises was practiced, but it had a purely external and coercive nature, which prevented the initiative of the concerned social groups. The workers were under "comprehensive care and vigilant supervision of the administration", mechanically submitting to the owners, whose power allegedly borrowed their authority from the state. L. Tal noted that " ... the police point of view prevailed over the social point of view" 20 , acknowledging a large number of special laws on factory industry in Russian Empire. L. Tal summed up "industrial law of this era was... centralized or public law; it brought up the branch of administrative (police) law"21.

The supporters of the optimal interaction for state intervention and public initiative took an intermediate place in the attempts of the urgent labor issue solving. In the early twentieth century factory legislation researcher B. Belikov wrote that even the most intransigent supporters of the individualistic direction of social policy began to recognize the "right and duty of a legislator to interfere in relationship between employers and workers" 22 .

At the end of the nineteenth century, a well-known Russian scientist I. Tarasov stated that the least intervention of the state in the sphere of safety, sanitary norms and factory life would be logical, since ensuring the proper conditions of the latter ones would only help to increase labor productivity. "However, unthoughtful self-interest in the alliance with the dark ignorance put the states in the need in this area, first of all, to start compulsory measures" 23 .

${ }^{19}$ Hrytsenko I. S. (2013) Istorychni peredumovy zaprovadzhennia administratyvnoi yustytsii: ukrainska tradytsiia [Historical Background for Administrative Justice: Ukrainian Tradition]. Administrative law and process, no. 1, p. 107.

${ }^{20}$ Tal' L.S. (1918) Ocherki promyshlennogo prava [Essays on Industrial Labor Law]. Moscow: Moskovskoe nauchnoe izdatel'stvo. (in Russian), pp. 12-13.

${ }^{21}$ Tal' L.S. (1918) Ocherki promyshlennogo prava [Essays on Industrial Labor Law]. Moscow: Moskovskoe nauchnoe izdatel'stvo. (in Russian), p. 6.

${ }^{22}$ Belikov Zh.D. (1914) Zhenshchina $v$ promyshlennoy inspektsii Zapada: $k$ voprosu o vvedenii zhenskoy fabrichnoy inspektsii v Rossii. [A woman in the industrial inspection of the West: on the introduction of a female factory inspection in Russia]. Tver: Tipo-Litografiya M.V. Blinova (in Russian), p. 3.

${ }^{23}$ Tarasov I.T. (1897) Ocherk nauki politseyskago prava [Essay on the Science of The Police Law]. Moscow: Visochayshe utverzhd. T-stvo «Pechatnya S.P. Yakovleva». (in Russian), p. 677. 
State attitude change toward the labor issue was clearly imprinted. The concentration processes of production and capital, which began in the 80-ies of the nineteenth century, developed during economic crisis of 1900-1903 and reached their climax during $\mathrm{WWI}^{24}$. The state emerged as an economic entity in such sectors of the economy, which were considered to be an exclusively private sphere. As a consequence, on the one hand, it was a prerequisite for an anti-individualistic attitude to contractual freedom, and on the other hand - a prerequisite for the socialization idea for civil law emergence, ie, the prevailing interests of the whole society over the interests of its individual members and thus state interference justification within the freedom of contractual relationship in individual cases but also as a "socio-political principle that should be laid in a basis of the legal system" 25 .

\section{Prerequisites for factory inspection institution establishment}

The emergence of factory legislation was largely driven by social factors, among which there were the demands of workers to reduce the level of exploitation of their labor ${ }^{26}$. The interestss of people stipulated the emergence of legislation for their labor protection.

Workers' strikes first swept in 1875-1882 in Yuzivka, Orekhovo-Zuev, St. Petersburg, Warsaw, Narva, then in 1884 - early 1885 in Moscow and Vladimir provinces, forced the government to analyze their causes. As a result, it was found that the prerequisites for factory uproar were not accidental in nature and were caused by improper relations between manufacturers and workers: breach of employment conditions; reduction of wages; fines that were unjustifiably imposed on workers and amounted to up to 40 percent of wages; obligation to buy goods within the factory at inflated prices, etc ${ }^{27}$. The result of the investigation was introduction of the draft "Rules on the supervision over the establishments dealing with factory industry and on the relations between the owners and their workers" for the

24 Mashkin O.M. (2010) Monopolizatsiia kapitalistychna [Capitalist Monopolization] Entsyklopediia istorii Ukrainy [Encyclopedia of Ukrainian history], vol. 7. Kyiv: V-vo «Naukova dumka». Retrieved from: http://www.history.org.ua/?termin=Monopolizatsiia_kapitalistychna (accessed 10 October 2019).

25 Kaminskaya P.D. (1927) Sovetskoe trudovoe pravo: obzor deystvuyushchego zakonodatel'stva s prakticheskim komentariem [Soviet labor law: a review of existing legislation with practical comment]. Kharkiv: Yurid. izd-vo Narkomyusta USSR (in Ukrainian), p. 25.

${ }^{26}$ Biriukova A. (2016) Okremi pytannia stanovlennia ta rozvytku trudovoho zakonodavstva v Ukraini [Some issues of formation and development of labor legislation in Ukraine]. Entrepreneurship, economy and law, no. 2, p. 66.

${ }^{27}$ Sliozberg' G.B. (1903) Iz tekushchey praktiki Ugolovnogo Kassatsionnogo Departamenta [From the current practice of the Criminal Cassation Department]. Herald of Law, no. 4, pp. 243-244. 
State Council, written by Minister of Finance and Minister of Internal Affairs. The explanatory note for the project stated: "Personal recruitment for labor in factories ... it is entirely within the field of civil relations, interests of the state..., it is a subject to the police improvement; thus, by virtue of its importance for public order, one cannot but enter the area of special concern and supervision of the government" 28 .

Unsatisfactory working conditions in factories became a sign of imminent threat to national security, growing unrest of workers, the need to regulate relations between industrialists and workers in the conditions of serfdom remnants - all this led to the emergence of factory legislation and factory inspection - the body to supervise compliance with the former one by manufactures. One of the Russian leading police law specialists, V. Deryuzhinsky defined factory legislation as a set of rules governing the relationship between businessmen and workers, protecting the interests of the latter from the adverse effects of large-scale production ${ }^{29}$.

Exploring the state of industry and working conditions in Western Europe, Russian economist I. Kulisher, reasonably concluded that the development of factory legislation showed the passage of the same stages in different countries, consistently covering some then other working conditions and working class groups, creating substantially similar norms. Such uniformity of factory legislation, that incidentally embodied the legislation on labor protection was explained by the scientist as the general principles of social development, produced by "economic science and life" and homogeneous throughout the civilized world "principles of morality and hygiene" 30 . This substantiated the attempt to develop the standards aimed at worker labor protection of international level at the end of the nineteenth century. In March 1890, an international conference was held in Berlin with the participation of representatives from fifteen European countries. One of the important decisions made by the participants was the recommendation to subordinate labor legislation supervision to inspectors, independent on both manufacturers and workers ${ }^{31}$.

${ }^{28}$ Sliozberg' G.B. (1903) Iz tekushchey praktiki Ugolovnogo Kassatsionnogo Departamenta [From the current practice of the Criminal Cassation Department]. Herald of Law, no. 4, p. 244.

${ }^{29}$ Deryuzhinskiy V. F. (1917) Politseyskoe pravo: posobie dlya studentov [Police Law: Student Manual]. Petrograd: Senat. tip. (in Russian), p. 478-479.

${ }^{30}$ Kulisher I.M. (1923) Promyshlennost' $i$ usloviya truda na Zapade v XIX stoletii [Industry and working conditions of the West in the 19th century]. Petrograd: Izdatel'stvo Brokgauz Efron (in Russian), p. 229.

${ }^{31}$ Kulisher I.M. (1923) Promyshlennost' $i$ usloviya truda na Zapade v XIX stoletii [Industry and working conditions of the West in the 19th century]. Petrograd: Izdatel'stvo Brokgauz Efron (in Russian), p. 231. 
There are many examples from factory legislation history of different countries, especially the first laws aimed at working hour regulation, which was neglected by manufacturers regarding the prescriptions of their norms. Therefore in a certain period of time there was an enlightment that "laws without their compliance, orders and prohibitions without supervision are powerless and remain only on paper" ${ }^{32}$. Many scientists addressed to law enforcement and its effectiveness at the end of the nineteenth century, ranging from the author of sociological theory of state formation, development and law - Rudolf von Hering with his "implementation is life and truth of the law, is the law itself" ${ }^{33}$ to I. Novgorodtsev, Russian lawyer and philosopher who wrote: "If there are rules and supervision of their implementation, there is law and power or, quoting the old axiom, ubi societas, ibi jus" (law is there, where society is - from Latin. $)^{34}$. P. Obninsky, Russian lawyer and public figure known for defending the interests of workers in Moscow Prisutstvie on factory affairs, paid attention to the same problem in the article "Legal protection of children working in workshops and issues of its nearest future"; the author warned that every law that aims at collective protection of interests, no matter how perfect and predictable it is, retains value as much as it is fulfilled, otherwise turning into a "dead, needless letter of the law" 35 .

Eugene Ehrlich, a well-known Austrian scientist-lawyer, one of the founders for sociology of law, studying the real "living" law of Bukovina, incidentally came to conclusion that the administrative activity of the country was more effective in comparison with the condition of legislation. According to his observations, in the countries with backward legislation and effective work of factory inspection, the labor protection was better organized than in the countries with advanced legislation and poorly developed factory inspection $^{36}$.

${ }^{32}$ Kulisher I.M. (1923) Promyshlennost' i usloviya truda na Zapade v XIX stoletii [Industry and working conditions of the West in the 19th century]. Petrograd: Izdatel'stvo Brokgauz Efron (in Russian), p. 250.

${ }^{33}$ Iering R. (1905) Yuridicheskaya tekhnika [Legal Technique] St. Petersburg. (in Russian), p. 18.

${ }^{34}$ Novgorodtsev P.I. (1917) Vvedenie v filosofiyu prava. III: Ob obshchestvennom ideale [Introduction to the philosophy of law. III: On the social ideal]. Vol. I. Moscow: Tipo-litografiya T-va I.N. Kushnerev i K. (in Russian), p. 458.

${ }^{35}$ Obninskiy p. N. (1890) Yuridicheskaya okhrana detey, rabotayushchikh v masterskikh, i voprosy ee blizhayshego budushchego [Legal protection of children working in workshops and issues of its near future] Legal messenger, vol. V, no. 5-6, p. 181.

${ }^{36}$ Il'inskiy I.D. (1925) Pravo i byt [Law and Life]. Leningrad; Moscow: Gosudarstvennoe izdatel'stvo (in Russian), p. 23. 


\section{The legal nature for supervision and control of compliance with factory legislation}

In the scientific literature of the late XIX - early XX centuries, there were made first attempts to define the concepts, essential features, assignments, types and forms of supervision and control of compliance with factory legislation. It is worth agreeing with the repeatedly expressed opinion of scientists that both supervision and control are multifaceted categories, and the definition of their essential features depends on the point of view regarding the concept of control and supervision as a legal phenomenon for the state and science ${ }^{37}$. Therefore, it is important to find out how surveillance and control have been positioned in general and in compliance with factory legislation by scholars of the imperial period in particular. The administrativist-scientist A. Elistratov extending the regulatory influence of administrative law to the institution of administrative supervision, defined the latter as a "means of ensuring legality in management"38. A. Elistratov identified the following forms of "supervision or control": (1) reporting; (2) audit; (3) continuous surveillance. Thus, the terms "supervision" and "control" were used by the scientist as synonymous words, referring the first and foremost to the notion of supervision from the position of protection function implementation for public law as a way of legality ensuring. Analyzing the "Volumes of reports" from factory inspectors, A. Bykov concluded that they "...characterize the audits of our factory inspection mainly from the formal side", as most of described violation cases "... established for the supervision of formalities" ${ }^{39}$. As a modern Ukrainian scientist D. Arutyunyan rightly remarked, "...at the origins of administrative law science development, the state control was viewed in the same way as a modern vision of its functional side from the position of regulation, information gathering and surveillance (observation)" ${ }^{\text {"40 }}$.

37 Baklan O.V. (2003) Kontrolno-nahliadova diialnist ta administratyvnyi prymus $v$ sferi okhorony pratsi [Supervision and administrative coercion in the field of labor protection]. Kyiv: Poliprom. (in Ukrainian), p. 22.

38 Elistratov A.I. (1914) Osnovnyya nachala administrativnogo prava: Uchebnoe rukovodstvo [Fundamental Principles of Administrative Law: A Training Manual]. Moscow: Izdanie G.A. Lemmana (in Russian), p. 294.

${ }^{39}$ Bykov A.N. (1909) Fabrichnoe zakonodatel'stvo i razvitie ego $v$ Rossii: lektsii, chitannye $v$ Spb. politekhnikume i v Tekhnologicheskom institute v 1908-9 ucheb. Godu [Factory legislation and its development in Russia: lectures delivered in St. Petersburg. Polytechnic and Technological Institute in 1908 - 9 academic year]. St. Petersburg: Tip. «Pravda». (in Russian), p. 267.

${ }^{40}$ Arutiunian D.A. (2016) Derzhavnyi kontrol u sferi vedennia lisovoho hospodarstva v Ukraini: teoretyko-pravovi zasady doslidzhennia [State control in the field of forestry in Ukraine: theoretical and legal bases of the research]. Scientific Bulletin of Kherson State University. Legal Sciences Series, vol. 5, no. 2, p. 9. 
The researcher of commercial and industrial law V. Udintsev distinguished the following types of state supervision: (1) the highest supervision which was carried out by the Chief Prisutstvie of mining and factory affairs; (2) "nearterm" supervision by district factory inspection officers; (3) local supervision by senior inspectors and precinct officers; (4) supervision of the "general police" in the cases provided for by law, namely: supervision of the teenagers work (Art. 124-125 of the Statute of Industry), supervision of compliance with the improvement and order of factories and plants (Art. 148); (5) the police supervision over the cash settlements for workers ${ }^{41}$.

The administrativists-scientists turned to the functional aspects of supervision and control study at the end of the nineteenth and early twentieth centuries. Thus, I. Tarasov emphasized that if a desired requirement for separation of control from management was not observed, the certain rules had to be observed during the implementation, among them: (1) controlling bodies should be independent of the controlled ones; 2) result of the control must have legal consequences; (3) supervisory authorities should not be involved in management actions to comply with their orders and regulations, confining themselves to purely controlling functions ${ }^{42}$. The scientist drew attention to the need of extensive supervision and control over public persons and individuals (industrialists, in particular) to ensure public and state interests.

Russia clearly identified and actively manifested the prerequisites for labor law science formation at the turn of the nineteenth and twentieth centuries. The labor scientists, ie, representatives of academic science; factory inspectors; government officials and business representatives, addressed the legal nature of the supervision and control of compliance with factory legislation $^{43}$.

L. Tal said, "the order of an enterprise is normalized by the state in a certain part. So this part constitutes the subject of a legal discipline called labor law, industrial, or social law"44. The study of labor law subject at that time meant the study of labor law formation. V. Litvinov-Falinsky substantiated the complex structure of the subject of labor law, including

${ }^{41}$ Udintsev V.A. (1907) Russkoe torgovo-promyshlennoe pravo [Russian commercial and industrial law]. Kyiv: Tipografiya I. I. Chokolova (in Russian), p. 312-314.

${ }^{42}$ Tarasov I.T. (1910) Lektsii po politseyskomu (administrativnomu) pravu. Tom vtoroy. Obshchaya chast' [Lectures on the police (administrative) law. Volume Two. A common part]. Moscow: Pechatnya A.I. Snegirevoy (in Russian), p. 197.

${ }^{43}$ Lushnikov A.M. (2010) Rossiyskaya shkola trudovogo prava i prava sotsial'nogo obespecheniya: portrety na fone vremeni (sravnitel'no-pravovoe issledovanie) [[Russian school of labor law and social security law: portraits at the background of time (comparative legal study)]. Monografiya: V 2 t. T. 1. Yaroslavl: YarGU (in Russian), p. 18.

${ }_{44}$ Tal' L.S. (1918) Ocherki promyshlennogo prava [Essays on Industrial Labor Law]. Moscow: Moskovskoe nauchnoe izdatel'stvo. (in Russian), p. 2. 
employment relations between an employer and a worker but also control and supervision. He noted that due to factory legislation, hired labor relations were transferred from the field of private civil law to the field of public law ${ }^{45}$. The scientists attributed the regulation of employment and labor, ie, the relationship between workers and owners, based on the contract of personal employment (factory, labor or employment contract) to the subject of factory (labor) legislation. The proper order and improvement, as well as safety in factories and plants, were distinguished as the subject based on the content of Art. 1-2 of the Statute on Industrial Labor (1913 edition). At the same time, factory inspection was entrusted with "supervision of compliance with the rules governing duties and relationship between manufacturers and workers" (Art. 34, Paragraph 5, of the Statute on Industrial Labor).

L. Tal described supervision as "the only guarantee, recognized by our law," the application of legislative regulations adopted to restrain manufacturer's power and improve working conditions ${ }^{46}$. Criticizing the position of those scientists who attributed the contractual obligations to life and health protection of workers from harmful production factors, L. Tal justified their other legal nature. Such obligations stemmed from the "Rules on the compensation of casualties due to accidents to workers and employees, as well as members of their families in the enterprises of factory and mining industry" of June 2, 1903, determining the professional risks of a manufacturer, they were of non-contractual, public-law nature ${ }^{47}$. The essence of the new law did not mean to impose the obligation to compensate workers for disability or death on business owners. Such liability was established by general civil laws. The basic importance of this law was the detailed elaboration of the conditions for the implementation of its norms for the injured workers and their right to demand such remuneration ${ }^{48}$.

Thus, the recognition of the workers' right for labor protection and legal obligations laid on employers became the catalyst that caused the establishment and development of supervision (control) institution for compliance with factory (labor) legislation as a way for the rights securing.

45 Lushnikov A.M. (2010) Rossiyskaya shkola trudovogo prava i prava sotsial'nogo obespecheniya: portrety na fone vremeni (sravnitel'no-pravovoe issledovanie [Russian school of labor law and social security law: portraits at the background of time (comparative legal study)]. Monografiya: V 2 t. T. 1. Yaroslavl: YarGU (in Russian), p. 181.

46 Tal' L.S. (1918) Ocherki promyshlennogo prava [Essays on Industrial Labor Law]. Moscow: Moskovskoe nauchnoe izdatel'stvo. (in Russian), p. 12.

47 Tal' L.S. (1918) Ocherki promyshlennogo prava [Essays on Industrial Labor Law]. Moscow: Moskovskoe nauchnoe izdatel'stvo. (in Russian), p. 162.

${ }^{48}$ Shershenevich G.F. (1908) Kurs torgovogo prava. T. I: Vvedenie. Torgovye deyateli [Commercial law course. T. I: Introduction. Trading figures]. St. Petersburg: Izdanie Br. Bashmakovykh. (in Russian), p. 272. 
At that time, the problem of the distinction criteria between public and private law remained a leading issue in scientific community. Proponents of material theory, following Domitius Ulpian took the content of legal relations and interest as the basis. Representatives of the formal theory, following Rudolf von Ehring, saw a fundamental difference in the ways of the rights protection. The third - mixed theory - was based on a combination of both criteria. One way or another, but essentially unanimously attributing the relationship to the protection of workers' rights to public relation, the scientists determined the specifics to protect these rights. Public interest protection was entrusted to the public authorities, initiating this protection, and the latter took place in the context of an administrative or criminal process $^{49}$.

It is significant that during the period of strikes in the run-up to the 19051907 revolution, considering the Smirnov's (factory owner) case of the reduction in workers' wages due to the closure of the factory on non-holiday days and the changing prices which they had allegedly previously agreed with the workers, the Criminal Cassation Department stood up for protection of the workers. The reasoning part of the decision stated that the consent of the victim does not always rule out the crime of the act, namely that the solution of the problem depends on the specifics of the law protected relations whether it is of state importance or concerns only individuals. "There is no doubt", the Court concluded, “... all factory legislation... is of national importance. Only under this condition, factory legislation can have a raison d'être (the reason of being - from French), since it is not possible to speak of the contractual relations freedom in the mutual relations of manufacturers and factory workers with the full economic dependence of the latter on the representatives of capital" ${ }^{\prime 50}$, that is why, - it was justified due to the court decision, - "the whole branch of contractual relations in the interests of the common good is set by law within known limits, the contracting parties are endowed with special rights and duties, their fulfillment is ensured by administrative penalties in accordance with factory inspection order ... and its violation is punishable in accordance with public prosecution order" ${ }^{\prime 51}$.

O. Bykov, having analyzed in detail the development of factory legislation in European countries, concluded that the Austrian model was the most

${ }^{49}$ Khvostov V.M. (1908) Obshchaya teoriya prava. Elementarnyy ocherk [General theory of law. Elementary essay]. Moscow: Sklad izdaniya v knizhnykh magazinakh N.P. Karbasnikova. (in Russian), p. 76.

${ }^{50}$ Sliozberg' G.B. (1903) Iz tekushchey praktiki Ugolovnogo Kassatsionnogo Departamenta [From the current practice of the Criminal Cassation Department]. Herald of Law, no. 4, p. 244.

${ }^{51}$ Sliozberg' G.B. (1903) Iz tekushchey praktiki Ugolovnogo Kassatsionnogo Departamenta [From the current practice of the Criminal Cassation Department]. Herald of Law, no. 4, p. 240. 
similar to the factory inspection system in Russia. An Austrian industrial inspector had to oversee the implementation of the laws, through "benevolent control" to take care of the "implementation of the good points of the law for workers" and at the same time "...with the proper tact to support the manufacturers in their legal requirements, being a fair mediator between the two parties" ${ }^{, 52}$.

\section{CONCLUSIONS}

Thus, in scientific literature of the late XIX - early XX centuries, the need for a comprehensive influence of state institutions referring to all social relations in both Russian and Austro-Hungarian empires occupied the prevailing position. That situation showed the superiority of the police point of view over social one and the corresponding development in the specified period of factory (industrial) legislation as a part of the administrative (police) law. The emergence of factory legislation was largely driven by social factors, among which there were the demands of workers to reduce the level of exploitation of their labor. The interests of people led to the emergence of legislation aimed at protecting their work. Recognition of the workers' rights for labor protection and legal obligations laid on employers has become the catalyst that led to the establishment and development of the institution for supervision (control) of compliance with factory (labor) legislation as a way of ensuring these rights.

The scientific works of the late XIX - early XX centuries show that social purpose of supervision and control was realized through the protection function of public legal interest. The social essence of supervision and control institution was, on the one hand, to protect workers from over-exploitation and unsafe working conditions and, on the other hand, to create an equitable competition for manufacturers.

Supervision and control are multifaceted legal categories, and the definition of their essential features depends on the prevailing in the concept consideration point of view. The administrativists-scientists characterized supervision as a means of ensuring legitimacy in management. On the contrary, the first labor scientists viewed supervision as a guarantee of compliance with the rules of factory legislation.

According to the retrospective analysis, the development of factory legislation during the imperial period was characterized by supervision of its

\footnotetext{
${ }^{52}$ Bykov A.N. (1909) Fabrichnoe zakonodatel'stvo i razvitie ego v Rossii: lektsii, chitannye $v$ $S p b$. politekhnikume $i v$ Tekhnologicheskom institute v 1908-9 ucheb. Godu [Factory legislation and its development in Russia: lectures delivered in St. Petersburg. Polytechnic and Technological Institute in 1908-9 academic year]. St. Petersburg: Tip. «Pravda». (in Russian), p. $123-124$.
} 
implementation, which was realized in a mixed supervisory and control procedure. The governments of both Russian and Austro-Hungarian empires aimed at initial supervision or "benevolent control" over the implementation of factory legislation, interfering in the internal affairs of manufacturers as little as possible. However, under the influence of the labor movement, they had to add to the inspectors' powers broader control and reconciliation functions, which resulted in gaining a patronage nature for the inspection activities.

\section{SUMMARY}

The purpose of this study is to analyze the prerequisites and peculiarities of factory inspection institution as a specialized state body, designed to supervise and control the compliance with (labor, industrial) legislation; characteristics of social and legal aspects for supervision and control based on the analysis of scientific works by the scientists of the imperial period at the example of Ukraine as a part of Russian and Austro-Hungarian empires at the end of the 19th - beginning of the 20th century. The subject of the study is social and legal nature of supervision and control of compliance with factory legislation in historical retrospection. The study determined the predominance position towards a need for a comprehensive influence of state institutions on all public relations in both Russian and Austro-Hungarian empires in scientific literature of the imperial period; superiority of the police point of view over the social point of view; corresponding development of factory legislation as a component of administrative (police) law during a specified period. Social essence of supervising and controlling the compliance with factory legislation has been clarified. Thus, factory legislation, on the one hand, protected workers from over-exploitation and unsafe working conditions and, on the other hand, created an equitable competition for manufacturers. Taking into account the multidimensionality of supervision and control concept. It is emphasized that administratists-scientists characterized supervision as a means of ensuring legality in management. On the contrary to the above mentioned, first labour scientists considered supervision as a guarantee of compliance with the rules of factory legislation. The study proved that the factory legislation development was characterized by supervision over its realization and was implemented in a mixed supervisory and control procedure during the imperial period.

\section{REFERENCES}

1. Il'in A.Ya. (ex. ed.), Molodcov V.S., Korshunov A.M. (1970) Metodologicheskie problemy sovremennoj nauki [Methodological problems of modern science]. Moscow: Izd-vo Mosk. un-ta. (in Russian). 
2. Miroshnychenko M.I. (2012) Henezys pravovoi systemy Ukrainy: teoretyko-metodolohichnyi aspekt [Genesis of the legal system in Ukraine: theoretical and methodological aspect] (Doctor of Science Thesis), Kyiv: Open International University of Human Development "Ukraine".

3. Rabinovych P., Lutsiv O. (2017) Verkhovenstvo prava yak omriianyi rezultat zdiisnennia prav liudyny (pidkhody do interpretatsii, kryterii otsiniuvannia) [Rule of law as a dreamy result of the realization of human rights (approaches to interpretation, evaluation criteria)]. Law of Ukraine, no. 3, p. 100-106.

4. Honcharova K.V., Ivchuk Yu.Yu., Prylypko S.M., Yaroshenko O.M. (2014) Derzhava ta yii orhany yak subiekty trudovoho prava: teoretykoprykladnyi narys [The State and its Bodies as Subjects of Labor Law: Theoretical and Applied Outline]. Kharkiv: Pravo. (in Ukrainian).

5. Rabinovych P., Lutsiv O. (2017) Verkhovenstvo prava yak omriianyi rezultat zdiisnennia prav liudyny (pidkhody do interpretatsii, kryterii otsiniuvannia) [Rule of law as a dreamy result of the realization of human rights (approaches to interpretation, evaluation criteria)]. Law of Ukraine, no. 3, p. 100-106.

6. Miroshnychenko M.I. (2012) Henezys pravovoi systemy Ukrainy: teoretyko-metodolohichnyi aspekt [Genesis of the legal system in Ukraine: theoretical and methodological aspect] (Doctor of Science Thesis), Kyiv: Open International University of Human Development "Ukraine".

7. Zhyhalkin I.P. (2016) Systema pryntsypiv trudovoho prava v umovakh formuvannia pravovoi doktryny Ukrainy [System of labor law principles in the conditions of legal doctrine in Ukraine formation] (Doctor of Science Thesis), Kyiv: Taras Shevchenko National University of Kyiv.

8. Djugi L. (1909) Social'noe pravo, individual'noe pravo $i$ preobrazovanie gosudarstva [Social law, individual law and state transformation]. Moscow: Izdanie N.N. Klochkova. (in Russian).

9. Hlyz Yu. (2013) Miskyi holova Kyieva M. K. Rennenkampf: sproba sotsiolohichnoho portretu [Kyiv Mayor M.K. Rennenkampff: an attempt of a sociological portrait]. Local History. no. 2, p. 191-196.

10. Rennenkampf N.K. (1907) Juridicheskaja jenciklopedija [Legal Encyclopedia]. Kyiv; St. Petersburg: Izd. knigoprodavca N. Ja. Ogloblina [Lito-tipogr. T-va I.N. Kushnarev]. (in Russian).

11. Rennenkampf N.K. (1907) Juridicheskaja jenciklopedija [Legal Encyclopedia]. Kyiv; St. Petersburg: Izd. knigoprodavca N.Ya. Ogloblina [Lito-tipogr. T-va I.N. Kushnarev]. (in Russian).

12. Antonovich A.Ya. (1890) Kurs" gosudarstvennago blagoustroystva (politseyskago prava) [Public Improvement Course (Police Law)]. Kyiv: Tip. V.I. Zavadzkago, Vol. 1 (in Russian). 
13. Elistratov A.I. (1910) Uchebnik' russkago administrativnogo prava. Posobie $k$ ' lektsiyam [Textbook of Russian administrative law. Lecture Manual]. Moscow: Izdanie O-va Vzaimopomoshchi Studentov-Yuristov Mosk. Universiteta Vol. I. (in Russian).

14. Litvinov-Falinskiy V.P. (1904) Fabrichnoe zakonodatel'stvo $i$ fabrichnaya inspektsiya $v$ Rossii [Factory legislation and factory inspection in Russia]. St. Petersburg: tip. A.S. Suvorina. (in Russian).

15. Shershenevich G.F. (1908) Kurs torgovogo prava. T. I: Vvedenie. Torgovye deyateli [Commercial law course. T. I: Introduction. Trading figures]. St. Petersburg: Izdanie Br. Bashmakovykh. (in Russian).

16. Balitskiy G. (1907) Kakaya dolzhna byt' fabrichnaya inspektsiya [The way factory inspection should be]. Moscow. (in Russian).

17. Litvinov-Falinskiy V.P. (1904) Fabrichnoe zakonodatel'stvo $i$ fabrichnaya inspektsiya $v$ Rossii [Factory legislation and factory inspection in Russia]. St. Petersburg: tip. A. S. Suvorina. (in Russian).

18. Zav'yalov M.F. (2013) Nadzor $i$ kontrol' za soblyudeniem zakonodatel'stva o trude kak sposoby zashchity trudovykh prav rabotnikov [Supervision and monitoring of compliance with labor laws as the ways to protect labor rights of workers] (PhD thesis abstract), Moscow: Institute of Legislation and Comparative Law under the Government of Russian Federation.

19. Hrytsenko I.S. (2013) Istorychni peredumovy zaprovadzhennia administratyvnoi yustytsii: ukrainska tradytsiia [Historical Background for Administrative Justice: Ukrainian Tradition]. Administrative law and process, no. 1 , p. 107-121.

20. Tal' L.S. (1918) Ocherki promyshlennogo prava [Essays on Industrial Labor Law]. Moscow: Moskovskoe nauchnoe izdatel'stvo. (in Russian).

21. Tal' L.S. (1918) Ocherki promyshlennogo prava [Essays on Industrial Labor Law]. Moscow: Moskovskoe nauchnoe izdatel'stvo. (in Russian).

22. Belikov Zh.D. (1914) Zhenshchina $v$ promyshlennoy inspektsii Zapada: $k$ voprosu o vvedenii zhenskoy fabrichnoy inspektsii $v$ Rossii. [A woman in the industrial inspection of the West: on the introduction of a female factory inspection in Russia]. Tver: Tipo-Litografiya M. V. Blinova (in Russian).

23. Tarasov I.T. (1897) Ocherk nauki politseyskago prava [Essay on the Science of The Police Law]. Moscow: Visochayshe utverzhd. T-stvo "Pechatnya S. P. Yakovleva". (in Russian).

24. Mashkin O.M. (2010) Monopolizatsiia kapitalistychna [Capitalist Monopolization] Entsyklopediia istorii Ukrainy [Encyclopedia of Ukrainian history], vol. 7. Kyiv: V-vo "Naukova dumka". Retrieved from: http://www.history.org.ua/?termin=Monopolizatsiia_kapitalistychna (accessed 10 October 2019). 
25. Kaminskaya P.D. (1927) Sovetskoe trudovoe pravo: obzor deystvuyushchego zakonodatel'stva s prakticheskim komentariem [Soviet labor law: a review of existing legislation with practical comment]. Kharkiv: Yurid. izd-vo Narkomyusta USSR (in Ukrainian).

26. Biriukova A. (2016) Okremi pytannia stanovlennia ta rozvytku trudovoho zakonodavstva $\mathrm{v}$ Ukraini [Some issues of formation and development of labor legislation in Ukraine]. Entrepreneurship, economy and law, no. 2, p. 66-70.

27. Sliozberg' G.B. (1903) Iz tekushchey praktiki Ugolovnogo Kassatsionnogo Departamenta [From the current practice of the Criminal Cassation Department]. Herald of Law, no. 4, pp. 231-256.

28. Sliozberg' G.B. (1903) Iz tekushchey praktiki Ugolovnogo Kassatsionnogo Departamenta [From the current practice of the Criminal Cassation Department]. Herald of Law, no. 4, pp. 231-256.

29. Deryuzhinskiy V.F. (1917) Politseyskoe pravo: posobie dlya studentov [Police Law: Student Manual]. Petrograd: Senat. tip. (in Russian).

30. Kulisher I.M. (1923) Promyshlennost' $i$ usloviya truda na Zapade $v$ XIX stoletii [Industry and working conditions of the West in the 19th century]. Petrograd: Izdatel'stvo Brokgauz - Efron (in Russian).

31. Kulisher I.M. (1923) Promyshlennost' i usloviya truda na Zapade $v$ XIX stoletii [Industry and working conditions of the West in the 19th century]. Petrograd: Izdatel'stvo Brokgauz - Efron (in Russian).

32. Kulisher I.M. (1923) Promyshlennost' $i$ usloviya truda na Zapade $v$ XIX stoletii [Industry and working conditions of the West in the 19th century]. Petrograd: Izdatel'stvo Brokgauz - Efron (in Russian).

33. Iering R. (1905) Yuridicheskaya tekhnika [Legal Technique] St. Petersburg. (in Russian).

34. Novgorodtsev P.I. (1917) Vvedenie $v$ filosofiyu prava. III: Ob obshchestvennom ideale [Introduction to the philosophy of law. III: On the social ideal]. Vol. I. Moscow: Tipo-litografiya T-va I.N. Kushnerev i K. (in Russian).

35. Obninskiy P.N. (1890) Yuridicheskaya okhrana detey, rabotayushchikh $\mathrm{v}$ masterskikh, i voprosy ee blizhayshego budushchego [Legal protection of children working in workshops and issues of its near future] Legal messenger, vol. V, no. 5-6, p. 179-188.

36. Il'inskiy I.D. (1925) Pravo i byt [Law and Life]. Leningrad; Moscow: Gosudarstvennoe izdatel'stvo (in Russian).

37. Baklan O.V. (2003) Kontrolno-nahliadova diialnist ta administratyvnyi prymus $v$ sferi okhorony pratsi [Supervision and administrative coercion in the field of labor protection]. Kyiv: Poliprom. (in Ukrainian). 
38. Elistratov A.I. (1914) Osnovnyya nachala administrativnogo prava: Uchebnoe rukovodstvo [Fundamental Principles of Administrative Law: A Training Manual]. Moscow: Izdanie G. A. Lemmana (in Russian).

39. Bykov A.N. (1909) Fabrichnoe zakonodatel'stvo i razvitie ego $v$ Rossii: lektsii, chitannye $v$ Spb. politekhnikume $i v$ Tekhnologicheskom institute v 1908-9 ucheb. Godu [Factory legislation and its development in Russia: lectures delivered in St. Petersburg. Polytechnic and Technological Institute in 1908-9 academic year]. St. Petersburg: Tip. "Pravda". (in Russian).

40. Arutiunian D.A. (2016) Derzhavnyi kontrol u sferi vedennia lisovoho hospodarstva v Ukraini: teoretyko-pravovi zasady doslidzhennia [State control in the field of forestry in Ukraine: theoretical and legal bases of the research]. Scientific Bulletin of Kherson State University. Legal Sciences Series, vol. 5, no. 2, p. 7-11.

41. Udintsev V.A. (1907) Russkoe torgovo-promyshlennoe pravo [Russian commercial and industrial law]. Kyiv: Tipografiya I.I. Chokolova (in Russian).

42. Tarasov I.T. (1910) Lektsii po politseyskomu (administrativnomu) pravu. Tom vtoroy. Obshchaya chast' [Lectures on the police (administrative) law. Volume Two. A common part]. Moscow: Pechatnya A. I. Snegirevoy (in Russian).

43. Lushnikov A.M. (2010) Rossiyskaya shkola trudovogo prava i prava sotsial'nogo obespecheniya: portrety na fone vremeni (sravnitel'no-pravovoe issledovanie) [[Russian school of labor law and social security law: portraits at the background of time (comparative legal study)]. Monografiya: V $2 \mathrm{t}$. T. 1. Yaroslavl: YarGU (in Russian).

44. Tal' L.S. (1918) Ocherki promyshlennogo prava [Essays on Industrial Labor Law]. Moscow: Moskovskoe nauchnoe izdatel'stvo. (in Russian).

45. Lushnikov A.M. (2010) Rossiyskaya shkola trudovogo prava i prava sotsial'nogo obespecheniya: portrety na fone vremeni (sravnitel'no-pravovoe issledovanie [Russian school of labor law and social security law: portraits at the background of time (comparative legal study)]. Monografiya: V 2 t. T. 1. Yaroslavl: YarGU (in Russian).

46. Tal' L.S. (1918) Ocherki promyshlennogo prava [Essays on Industrial Labor Law]. Moscow: Moskovskoe nauchnoe izdatel'stvo. (in Russian).

47. Tal' L.S. (1918) Ocherki promyshlennogo prava [Essays on Industrial Labor Law]. Moscow: Moskovskoe nauchnoe izdatel'stvo. (in Russian).

48. Shershenevich G.F. (1908) Kurs torgovogo prava. T. I: Vvedenie. Torgovye deyateli [Commercial law course. T. I: Introduction. Trading figures]. St. Petersburg: Izdanie Br. Bashmakovykh. (in Russian). 
49. Khvostov V.M. (1908) Obshchaya teoriya prava. Elementarnyy ocherk [General theory of law. Elementary essay]. Moscow: Sklad izdaniya v knizhnykh magazinakh N. P. Karbasnikova. (in Russian).

50. Sliozberg' G.B. (1903) Iz tekushchey praktiki Ugolovnogo Kassatsionnogo Departamenta [From the current practice of the Criminal Cassation Department]. Herald of Law, no. 4, pp. 231-256.

51. Sliozberg' G.B. (1903) Iz tekushchey praktiki Ugolovnogo Kassatsionnogo Departamenta [From the current practice of the Criminal Cassation Department]. Herald of Law, no. 4, pp. 231-256.

52. Bykov A.N. (1909) Fabrichnoe zakonodatel'stvo $i$ razvitie ego $v$ Rossii: lektsii, chitannye $v$ Spb. politekhnikume $i v$ Tekhnologicheskom institute v 1908-9 ucheb. Godu [Factory legislation and its development in Russia: lectures delivered in St. Petersburg. Polytechnic and Technological Institute in 1908-9 academic year]. St. Petersburg: Tip. "Pravda". (in Russian).

\section{Information about the author:}

Halyna Terela,

Candidate of Historical Sciences, Docent, Associate Professor at the Chair of Law, Poltava University of Economics and Trade

3, Koval str., Poltava, 36000, Ukraine ORCID ID: orcid.org/0000-0001-5102-7068 